\title{
The Association Between Serum Carnitine Level, Glucose Regulation, Body Fat and Nutrient Intake in Diabetic Individuals
}

\author{
Şehriban Duyar Özer ${ }^{1 *}$, Makbule Gezmen Karadağ ${ }^{1}$
}

\begin{abstract}
Carnitine ( $\beta$-hydroxy- $\gamma$-trimethyl amino butyrate) is, a vitamin-like substance carrying long-chain fatty acids into the mitochondrial matrix. Due to its effect in energy metabolism, carnitine plays an important role in controlling diabetes and its complications. Studies on this topic have often focused on carnitine supplementation. This study was planned to investigate the relationship between serum carnitine level, glucose regulation and body fat in diabetic patients. A total of 64 people between the ages of 30-55, 32 patients with type 2 diabetes and 32 healthy subjects, were included in the study. Individual lipid profiles, glucose, insulin and serum carnitine levels were analyzed, anthropometric measurements were taken and 24-hour recall food consumption was recorded. As a result, blood glucose, insulin, triglyceride, VLDL-C, HDL-C and HOMA-IR were found to be higher in diabetic individuals than healthy group $(\mathrm{p}<0,05)$. Serum carnitine levels were found to be significantly lower in diabetic male $(50,6 \pm 20,83 \mathrm{nmol} / \mathrm{mL})$ than in healthy male $(59,5 \pm 17,25 \mathrm{nmol} / \mathrm{mL})(\mathrm{p}<0,05)$. This difference was not statistically significant among female $(\mathrm{p}>0,05)$. It has been observed that intake of energy and macronutrients of diabetic individuals is generally lower than that of healthy individuals. Serum carnitine level was positively associated with polyunsaturated fatty acids and omega- 6 fatty acid intake in male in the healthy group showed a negative correlation with fiber intake in female in the healthy group $(p<0,05)$. There were negative correlations between serum carnitine level with body weight, body mass index and body fat mass in female in the healthy group $(\mathrm{p}<0,05)$. Individuals with diabetes are predisposed to dyslipidemia and insulin resistance. As a result; food consumption, and body fat affect individuals' serum carnitine levels in type-2 diabetes. Since there is not enough study evaluating the relationship between anthropometric measurements of individuals and serum carnitine levels, it is thought that this result will guide future studies.
\end{abstract}

Keywords: diabetes mellitus, carnitine, nutrition, insulin resistance, anthropometry

${ }^{1}$ Gazi University, Faculty of Health Sciences,

Department of Nutrition and Dietetics, Turkey

*Corresponding Author:

Sehriban DUYAR ÖZER

Gazi University, Faculty of Health Sciences,

Department of Nutrition and Dietetics, Turkey

E-mail: sehribanduyar@gmail.com

Telephone Number: +905070236395

DOI: 10.2478/ebtj-2021-0013

(C) 2021 Authors. This work was licensed under the

Creative Commons Attribution-NonCommercial NoDerivs 4.0 License.

\section{Introduction}

Carnitine ( $\beta$-hydroxy- $\gamma$-trimethyl amino butyrate) is a vitamin-like molecule and is responsible for transporting long-chain fatty acids (LCFA) to the mitochondrial matrix. (1, 2). In addition, carnitine facilitates the metabolism of aerobic carbohydrates by acting on the enzymes involved in metabolism and increases the rate of oxidative phosphorylation $(3,4)$. Affects glucose tolerance and insulin sensitivity by providing mitochondrial oxidation of long-chain acyl CoAs. (5).

Carnitine plays an important role in the control of diabetes due to its effect on energy metabolism (6). The increase in the use of carnitine, as well as the decrease in renal synthesis and reabsorption, cause a decrease in the carnitine level of the diabetic individual (7). A study comparing 50 diabetic and 35 healthy individuals found that the levels of carnitine $(52.77 \pm 12.34 \mu \mathrm{mol} / \mathrm{L})$ in diabetic patients were significantly lower than those of the healthy individual $(79.18 \pm 10.59 \mu \mathrm{mol} / \mathrm{L})(\mathrm{p}<0.05)(8)$. In a meta-analysis study, it was shown that serum carnitine levels were lower in diabetic individuals than in healthy individuals (9).

Owing to obesity and insulin resistance, increases in body fat mass have often been 
observed in diabetic individuals (10). In studies to reduce body fat accumulation, the hypothesis has been created that carnitine by increasing fatty acid oxidation prevents fat accumulation in tissues $(11,12)$. Studies have also shown that the substitution of carnitine deficiency in diabetic patients increases insulin sensitivity and glucose utilization in peripheral tissues and decreases insulin resistance $(8,13,14)$. In addition, it has been stated that with carnitine supplementation, blood lipid profile of diabetic individuals may improve. $(15,16)$.

Studies related to the effect of carnitine deficiency on diabetes markers and complications are more focused on carnitine supplementation in the diabetic individuals and there is a limited number of studies in the literature regarding the assessment of serum carnitine level $(9,16,17)$. Therefore, in this study, it is aimed to determine the relationship between serum carnitine level and insulin resistance, lipid profile and nutritional status and to contribute to the literature in this regard.

\section{Materials and Methods}

This study was conducted with a total of 64 individuals, aged 30-55 years, with 32 healthy and 32 type- 2 diabetic patients. Care was taken to ensure a homogeneous distribution between groups according to age, gender, and body mass index (BMI). The patient group is selected from among persons admitted to Gazi University Medical Faculty, Diabetes and Obesity Polyclinic on a voluntary basis. The healthy group was selected from among those who were admitted to Gazi University, Faculty of Health Sciences, Department of Nutrition and Dietetics and complied with the study protocol. Criteria for inclusion into the study for healthy individuals are the absence of any chronic illness, the absence of hormone therapy, and the absence of vitamin-mineral supplements. Individuals previously diagnosed with Type-2 diabetes by a doctor in the Department of Endocrinology, Faculty of Medicine, Gazi University, constituted the patient group. Patients who did not have any other diagnosed chronic diseases (hypertension, cardiovascular diseases, kidney diseases, etc.) and did not have any drugs, hormones or vitamins, minerals, plant supplements they regularly used other than insulin or oral anti-diabetic (OAD) were included the study.

From Gazi University Faculty of Medicine Clinical Investigation Ethics Board has approved 25901600/588 decision number and dated November 23, 2015, for the execution of the study.

In order to determine the energy and nutrient intake of individuals on a daily diet, 24-hour food consumption records were recorded by the researcher retrospectively. The average energy and nutrients of the consumed foods were calculated using the Nutrition Information System (BeBis) program (18).

Tanita BC418 body analyzer was used with the BIA method in determining the weight and body fat of the individuals. With the body weight $/$ height ${ }^{2}\left(\mathrm{~kg} / \mathrm{m}^{2}\right)$ equation, was calculated BMI of individuals, using the body weight and height measurements.

In blood samples taken after an 8-hour fasting from indi- viduals showed that serum carnitine, total cholesterol (TC), low-density lipoprotein cholesterol (LDL-C), high-density lipoprotein cholesterol (HDL-C), very low-density lipoprotein cholesterol (VLDL-C), triglyceride, blood glucose and insulin value were analyzed. For the assessment of insulin sensitivity homeostasis model assessment for insulin resistance (HOMA-IR) account is made using "fasting blood glucose ( $\mathrm{mmol} / \mathrm{L})$ $\mathrm{x}$ fasting insulin $(\mu \mathrm{U} / \mathrm{mL}) / 22.5^{\prime \prime}(19)$. Analysis of serum carnitine and other biochemical measurements was performed by a private biochemistry laboratory.

Independent sample t-test was used to compare two independent groups in the data with normal distribution and were shown with a mean $(\overline{\mathrm{X}})$, standard deviation (SD). "Mann-Whitney U" test was used for measurement values that are not normally distributed and were shown with median, interquartile range (IQR). Statistically significant values were accepted as $\mathrm{p}<0.05$.

\section{Results}

Findings from the study are given below and the general characteristics of the individuals are shown in Table 1. The median value of ages of the male participating in the study is 49.5 years in the patient group and 50 years in the healthy group. In females, in the patient is 46.5 years in the group and 40.5 years in the healthy group. There is not observed the statistically significant difference between the ages of patient and healthy groups according to gender $(\mathrm{p}>0,05)$. Body mass index averages were determined $27.9 \mathrm{~kg} / \mathrm{m}^{2}$ in both groups in males and $34.8 \mathrm{~kg}$ $/ \mathrm{m}^{2}$ in the patient group $34.2 \mathrm{~kg} / \mathrm{m}^{2}$ in the healthy group in females $(p>0,05)$. Since the individuals in the healthy group at the start of the study were matched to the BMI values in the patient group, no statistically difference was found in the BMI means in both genders (Table 1).

When the treatment modalities used by diabetic individuals were examined, it was determined that approximately half of the individuals in the patient group were using OAD alone (not shown in the table).

The individual's serum carnitine, biochemical parameters, and HOMA-IR values are given in Table 2. Serum carnitine level has been found $50.6 \mathrm{nmol} / \mathrm{mL}$ in the patient group and 59.5 $\mathrm{nmol} / \mathrm{mL}$ in the healthy group in males and there have been detected a statistically significant difference in terms of serum carnitine levels according to the disease of males $(p<0,05)$. Serum carnitine levels are $59.7 \mathrm{nmol} / \mathrm{mL}$ in the patient group, $62.3 \mathrm{nmol} / \mathrm{mL}$ in the healthy group in female. Although the serum carnitine level of the patient group was lower in female, the difference between them and the healthy group was not significant. ( $p>0,05)$. Serum glucose, insulin, VLDL cholesterol, HDL cholesterol, triglyceride levels and HOMA-IR values were found to be higher in individuals in the patient group compared to the healthy group $(\mathrm{p}<0,05)$. In addition to, the serum total cholesterol level in males in the patient group is higher than the healthy group $(\mathrm{p}<0,05)$.

The amount of energy and nutrients taken by individuals in the daily diet is given in Table 3 . According to the table, when 
Table 1. Individuals' age, BMI, and some anthropometric measurements

\begin{tabular}{|c|c|c|c|c|c|c|c|c|}
\hline & \multicolumn{4}{|c|}{ Male } & \multicolumn{4}{|c|}{ Female } \\
\hline & \multicolumn{2}{|c|}{ Patients (n:16) } & \multicolumn{2}{|c|}{ Healthy (n:16) } & \multicolumn{2}{|c|}{ Patients (n:16) } & \multicolumn{2}{|c|}{ Healthy (n:16) } \\
\hline & $\overline{\mathrm{X}} \pm \mathrm{SD}$ & Med $\pm I Q R$ & $\overline{\mathrm{X}} \pm \mathrm{SD}$ & Med \pm IQR & $\overline{\mathrm{X}} \pm \mathrm{SD}$ & Med \pm IQR & $\overline{\mathrm{X}} \pm \mathrm{SD}$ & Med $\pm \mathrm{IQR}$ \\
\hline \multirow[t]{2}{*}{ Age (yıl) } & $47,4 \pm 8,06$ & $49,5 \pm 9,25$ & $47,9 \pm 7,37$ & $50,0 \pm 6,25$ & $44,2 \pm 6,65$ & $46,5 \pm 4,50$ & $41,3 \pm 7,45$ & $40,5 \pm 11,75$ \\
\hline & & $Z=-0,076$ & $\mathrm{p}=0,940$ & & & $Z=-1,304$ & $\mathrm{p}=0,192$ & \\
\hline \multirow[t]{2}{*}{$\begin{array}{l}\text { Body weight } \\
\text { (kg) }\end{array}$} & $79,1 \pm 13,84$ & $78,4 \pm 17,13$ & $84,3 \pm 11,82$ & $82,9 \pm 16,20$ & $83,5 \pm 11,84$ & $79,5 \pm 17,13$ & $85,5 \pm 15,24$ & $85,2 \pm 19,53$ \\
\hline & & $\mathrm{t}=-1,140$ & $\mathrm{p}=0,263$ & & & $\mathrm{t}=-0,414$ & $\mathrm{p}=0,681$ & \\
\hline \multirow[t]{2}{*}{ BMI $\left(\mathrm{kg} / \mathrm{m}^{2}\right)$} & $27,9 \pm 4,25$ & $27,4 \pm 6,04$ & $27,9 \pm 3,70$ & $27,4 \pm 4,46$ & $34,8 \pm 5,21$ & $33,9 \pm 8,18$ & $34,0 \pm 5,96$ & $33,1 \pm 7,94$ \\
\hline & & $t=-0,010$ & $\mathrm{p}=0,992$ & & & $\mathrm{t}=0,389$ & $\mathrm{p}=0,700$ & \\
\hline \multirow[t]{2}{*}{$\begin{array}{l}\text { Body fat per- } \\
\text { centage (\%) }\end{array}$} & $25,9 \pm 5,35$ & $25,3 \pm 10,53$ & $27,7 \pm 6,58$ & $27,3 \pm 6,65$ & $41,9 \pm 4,04$ & $41,7 \pm 7,80$ & $42,4 \pm 5,82$ & $43,0 \pm 7,28$ \\
\hline & & $\mathrm{t}=-0,834$ & $\mathrm{p}=0,411$ & & & $t=-0,275$ & $\mathrm{p}=0,785$ & \\
\hline \multirow[t]{2}{*}{$\begin{array}{c}\text { Body fat mass } \\
(\mathrm{kg})\end{array}$} & $21,1 \pm 7,69$ & $19,3 \pm 12,92$ & $23,9 \pm 8,55$ & $23,5 \pm 8,47$ & $35,4 \pm 8,19$ & $32,87 \pm 14,57$ & $37,0 \pm 11,23$ & $36,91 \pm 10,62$ \\
\hline & & $t=-0,951$ & $\mathrm{p}=0,349$ & & & $t=-0,465$ & $\mathrm{p}=0,646$ & \\
\hline
\end{tabular}

Independent sample t-test was used to compare two independent groups in the data with normal distribution, and the mean and standard deviation were used. The "Mann-Whitney U" test was used to compare two independent groups in the data with no normal distribution and is shown by the median \pm IQR.

individuals are compared according to the disease, significant differences were observed in some parameters in terms of food consumption $(\mathrm{p}<0,05)$. Energy, carbohydrate, fiber, and protein intake were found to be significantly lower in individuals in the patient group than in the healthy group $(\mathrm{p}<0,05)$. However, there wasn't observed significant differences between the groups in the intakes of animal protein $(\mathrm{g})$, total fat $(\mathrm{g})$, polyunsaturated fatty acids (PUFA), omega-3 (n-3) and omega- 6 $(\mathrm{p}>0,05)$.

The relationship between serum carnitine levels of individuals and some parameters is given in Table 4 . There was observed negative relationship between serum carnitine levels and fiber intake in female in the healthy group $(\mathrm{p}<0,05 ; \mathrm{r}=-0,503)$ There is a positive directional relationship between serum carnitine levels of the males in the healthy group and PUFA $(\mathrm{p}<0,05$; $r=0,691$ ), as the intake of PUFA increases, the level of serum carnitine increases. Similarly, there has been found a positive relationship between the serum carnitine levels of the males in the healthy group and the intake of $n-6$ fatty acids $(p<0,05$; $\mathrm{r}=0,706)$.

It has not been found a significant relationship between serum glucose, insulin levels and HOMA-IR value with serum carnitine levels in both genders according to disease ( $p>0,05)$. The negative relationship was found between serum carnitine levels and body weight and BMI of female in the healthy group ( $\mathrm{p}<0,05 ; \mathrm{r}=-0,676$ ve $\mathrm{p}<0,05 ; \mathrm{r}=-0,632$ respectively). As body weight and BMI increase, serum carnitine level decreases. There has been observed also a negative relationship between serum carnitine levels and body fat mass $(\mathrm{kg})$ in female in the healthy group $(\mathrm{p}<0,05 ; \mathrm{r}=0,036)$. As the body fat mass increas- es, the level of serum carnitine decreases.

\section{Discussion}

Carnitine is a vitamin-like compound that allows the passage of LCFA through the mitochondrial membrane for $\beta$-oxidation $(1,2)$. In addition, carnitine affects insulin sensitivity and glucose utilization in tissues $(1,5)$. It has been reported that carnitine levels are lower in diabetic patients than in healthy individuals due to increased carnitine use in the body and decreased renal reabsorption in diabetic individuals $(8,9)$. In type 2 diabetes, circulating fatty acid levels are higher in the postprandial state (20). Since the main task of carnitine is to form esters with organic acids, it can reduce the accumulated acyl CoA derivatives and / or metabolites by transporting them from mitochondria (21). This is thought to cause a decrease in serum carnitine levels in individuals with diabetes.

In a study conducted for this purpose: diabetic rats were examined after 30 days, it has been observed the plasma carnitine level decreased and urine carnitine excretion increased (7). In another study, 20 diabetic patients and 18 healthy subjects were compared and plasma carnitine levels were determined lower in diabetic individuals than healthy individuals $(21 \pm 2 \mu \mathrm{mol}$ / L and $35 \pm 2 \mu \mathrm{mol} / \mathrm{L}$, respectively) $(\mathrm{p}<0.005)(22)$. Similarly, a study comparing 50 diabetic patients and 35 healthy individuals have been identified that carnitine levels $(52.77 \pm 12.34$ $\mu \mathrm{mol} / \mathrm{L})$ in diabetic individuals were lower than healthy individuals $(79.18 \pm 10.59 \mu \mathrm{mol} / \mathrm{L})(\mathrm{p}<0.05)(8)$. In this study, serum carnitine levels were found to be statistically lower in patient group $(50,6 \pm 20,85 \mathrm{nmol} / \mathrm{mL})$ in males than healthy group $(59,5 \pm 17,25 \mathrm{nmol} / \mathrm{mL})(\mathrm{p}<0,05)$. But; although the serum car- 
Table 2. Individuals' serum carnitine, biochemical parameters and HOMA-IR values

\begin{tabular}{|c|c|c|c|c|c|c|c|c|}
\hline \multirow[b]{3}{*}{ Parameters } & \multicolumn{4}{|c|}{ Male } & \multicolumn{4}{|c|}{ Female } \\
\hline & \multicolumn{2}{|c|}{ Patients (n:16) } & \multicolumn{2}{|c|}{ Healthy (n:16) } & \multicolumn{2}{|c|}{ Patients (n:16) } & \multicolumn{2}{|c|}{ Healthy (n:16) } \\
\hline & $\overline{\mathrm{X}} \pm \mathrm{SD}$ & Med $\pm I Q R$ & $\overline{\mathrm{X}} \pm \mathrm{SD}$ & Med $\pm I Q R$ & $\overline{\mathrm{X}} \pm \mathrm{SD}$ & Med $\pm I Q R$ & $\overline{\mathrm{X}} \pm \mathrm{SD}$ & Med $\pm I Q R$ \\
\hline \multirow[t]{2}{*}{$\begin{array}{l}\text { Serum gluco- } \\
\text { se }(\mathrm{mg} / \mathrm{dL})\end{array}$} & $143,2 \pm 48,30$ & $125,5 \pm 48,25$ & $85,6 \pm 10,97$ & $82,5 \pm 16,25$ & $162,3 \pm 71,19$ & $137,5 \pm 88,50$ & $84,1 \pm 7,55$ & $83,5 \pm 12,00$ \\
\hline & & $Z=-4,523$ & $\mathrm{p}=0,000^{* *}$ & & & $Z=-4,638$ & $\mathrm{p}=0,000^{* *}$ & \\
\hline \multirow[t]{2}{*}{$\begin{array}{l}\text { Serum insulin } \\
\qquad(\mathrm{mU} / \mathrm{L})\end{array}$} & $14,6 \pm 8,21$ & $13,7 \pm 13,40$ & $8,4 \pm 3,87$ & $8,2 \pm 5,28$ & $18,2 \pm 9,04$ & $16,7 \pm 12,91$ & $6,7 \pm 2,67$ & $5,9 \pm 3,23$ \\
\hline & & $t=2,734$ & $\mathrm{p}=0,012^{*}$ & & & $Z=-4,372$ & $\mathrm{p}=0,000^{* *}$ & \\
\hline \multirow[t]{2}{*}{$\begin{array}{l}\text { Serum total } \\
\text { cholesterol } \\
(\mathrm{mg} / \mathrm{dL})\end{array}$} & $193,8 \pm 24,67$ & $193,1 \pm 45,08$ & $152,7 \pm 31,51$ & $154,5 \pm 48,00$ & $191,2 \pm 66,55$ & $186,6 \pm 74,18$ & $155,1 \pm 25,60$ & $156,0 \pm 30,75$ \\
\hline & & $\mathrm{t}=4,104$ & $\mathrm{p}=0,000^{* *}$ & & & $t=2,028$ & $\mathrm{p}=0,057$ & \\
\hline \multirow[t]{2}{*}{$\begin{array}{l}\text { Serum LDL-C } \\
(\mathrm{mg} / \mathrm{dL})\end{array}$} & $119,6 \pm 20,21$ & $117,8 \pm 29,25$ & $109,8 \pm 25,26$ & $109,5 \pm 39,75$ & $121,7 \pm 42,46$ & $116,2 \pm 55,55$ & $106,9 \pm 17,87$ & $105,0 \pm 20,75$ \\
\hline & & $\mathrm{t}=1,210$ & $\mathrm{p}=0,236$ & & & $\mathrm{t}=1,285$ & $\mathrm{p}=0,213$ & \\
\hline \multirow[t]{2}{*}{$\begin{array}{c}\text { Serum } \\
\text { HDL-C (mg/ } \\
\text { dL) }\end{array}$} & $40,0 \pm 7,33$ & $39,6 \pm 10,60$ & $32,2 \pm 6,91$ & $31,9 \pm 11,85$ & $48,1 \pm 12,28$ & $47,4 \pm 18,90$ & $38,4 \pm 8,23$ & $37,2 \pm 10,33$ \\
\hline & & $t=3,116$ & $\mathrm{p}=0,004^{* *}$ & & & $t=2,620$ & $\mathrm{p}=0,014^{*}$ & \\
\hline \multirow{2}{*}{$\begin{array}{c}\text { Serum } \\
\text { VLDL-C (mg/ } \\
\text { dL) }\end{array}$} & $34,2 \pm 10,78$ & $33,1 \pm 14,45$ & $19,4 \pm 6,53$ & $20,0 \pm 9,00$ & $36,9 \pm 19,46$ & $33,1 \pm 38,61$ & $18,2 \pm 10,34$ & $14,0 \pm 7,25$ \\
\hline & & $t=4,691$ & $\mathrm{p}=0,000^{* *}$ & & & $Z=-3,209$ & $\mathrm{p}=0,001^{* *}$ & \\
\hline \multirow[t]{2}{*}{$\begin{array}{l}\text { Serum trigly- } \\
\text { cerides (mg/ } \\
\text { dL) }\end{array}$} & $171,0 \pm 53,88$ & $165,9 \pm 72,15$ & $96,7 \pm 33,07$ & $99,1 \pm 46,43$ & $193,1 \pm 117,87$ & $165,5 \pm 193,05$ & $91,2 \pm 51,83$ & $70,8 \pm 36,08$ \\
\hline & & $\mathrm{t}=4,701$ & $\mathrm{p}=0,000^{* *}$ & & & $\mathrm{Z}=-3,128$ & $\mathrm{p}=0,002^{* *}$ & \\
\hline \multirow[t]{2}{*}{ HOMA-IR } & $5,2 \pm 3,33$ & $4,2 \pm 5,32$ & $1,8 \pm 0,91$ & $1,7 \pm 1,53$ & $7,0 \pm 3,62$ & $6,7 \pm 6,83$ & $1,4 \pm 0,66$ & $1,2 \pm 0,76$ \\
\hline & & $t=3,911$ & $\mathrm{p}=0,001^{* *}$ & & & $\mathrm{Z}=-4,711$ & $\mathrm{p}=0,000^{* *}$ & \\
\hline \multirow[t]{2}{*}{$\begin{array}{l}\text { Serum carni- } \\
\text { tine (nmol/ } \\
\mathrm{mL})\end{array}$} & $51,6 \pm 12,08$ & $50,6 \pm 20,83$ & $68,1 \pm 26,57$ & $59,5 \pm 17,25$ & $56,9 \pm 10,91+$ & $59,7 \pm 12,65+$ & $66,7 \pm 23,23$ & $62,3 \pm 15,43$ \\
\hline & & $Z=-2,450$ & $\mathrm{p}=0,014^{*}$ & & & $Z=-1,319$ & $\mathrm{p}=0,187$ & \\
\hline
\end{tabular}

${ }^{*} \mathrm{p}<0,05,{ }^{* *} \mathrm{p}<0,01$. Independent sample $\mathrm{t}$-test was used to compare two independent groups in the data with normal distribution, and the mean and standard deviation were used. The "Mann-Whitney $U$ " test was used to compare two independent groups in the data with no normal distribution and is shown by the median \pm IQR. LDL-C: Low-density lipoprotein cholesterol, HDL-C: High-density lipoprotein cholesterol, VLDL-C: Very low-density lipoprotein cholesterol, HOMA-IR: homeostasis model assessment of insulin resistance.

+ : one of the blood samples is not included in the analysis because it is hemolysis.

nitine level $(59.7 \pm 12.65 \mathrm{nmol} / \mathrm{mL})$ of the patient group in female was lower than that of the healthy group $(62.3 \pm 15.43$ $\mathrm{nmol} / \mathrm{mL}$ ), a significant difference wasn't observed $(\mathrm{p}>0,05)$ (Table 2). The data obtained from this study are similar to other studies in the literature. Total protein intake (g) was generally higher in the healthy group compared to the patient group ( $\mathrm{p}$ $<0.05)$. However, animal protein intake $(\mathrm{g})$ is slightly lower in healthy female (Table 3). This situation leads to a reduction of with dietary consumed carnitine sources. Since the serum carnitine level also depends on the amount of carnitine taken with the diet, it is thought that serum carnitine levels in the healthy group of female are affected by food consumption. In addition, it was thought that body composition in women may also have affected serum carnitine levels.

Paying attention to energy intake in diabetic individuals, it is recommended to reduce energy intake, especially in people who are desired to lose body weigh (23). Also; the species of carbohydrate and fat taken with the carbohydrate and fat content of the diet is of importance in terms of ensuring of metabolic control and body weight control in diabetes (24). In a review made on this issue, it has been reported that low glycemic index and high fiber-containing foods regulate glucose 
Table 3. The amount of daily dietary energy and nutrients intake

\begin{tabular}{|c|c|c|c|c|c|c|c|c|}
\hline \multirow[b]{3}{*}{$\begin{array}{l}\text { Energy and } \\
\text { nutrients }\end{array}$} & \multicolumn{4}{|c|}{ Male } & \multicolumn{4}{|c|}{ Female } \\
\hline & \multicolumn{2}{|c|}{ Patients (n:16) } & \multicolumn{2}{|c|}{ Healthy (n:16) } & \multicolumn{2}{|c|}{ Patients (n:16) } & \multicolumn{2}{|c|}{ Healthy (n:16) } \\
\hline & $\overline{\mathrm{X}} \pm \mathrm{SD}$ & Med $\pm \mathrm{IQR}$ & $\overline{\mathrm{X}} \pm \mathrm{SD}$ & Med $\pm \mathrm{IQR}$ & $\overline{\mathrm{X}} \pm \mathrm{SD}$ & Med $\pm I Q R$ & $\overline{\mathrm{X}} \pm \mathrm{SD}$ & Med $\pm \mathrm{IQR}$ \\
\hline \multirow[t]{2}{*}{ Energy (kkal) } & $1957 \pm 455,25$ & $1843 \pm 742,11$ & $2832 \pm 524,52$ & $2815 \pm 584,60$ & $1563 \pm 395,75$ & $1557 \pm 367,31$ & $2341 \pm 623,61$ & $2246 \pm 924,82$ \\
\hline & & $t=-5,040$ & $\mathrm{p}=0,000^{* *}$ & & & $\mathrm{Z}=-3,731$ & $\mathrm{p}=0,000^{* *}$ & \\
\hline \multirow[t]{2}{*}{$\begin{array}{c}\text { Carbohydrate } \\
\text { (g) }\end{array}$} & $221,8 \pm 59,63$ & $207,4 \pm 66,05$ & $394,8 \pm 96,21$ & $387,8 \pm 53,82$ & $155,6 \pm 44,48$ & $149,0 \pm 45,48$ & $328,5 \pm 104,81$ & $346,3 \pm 144,56$ \\
\hline & & $t=-6,113$ & $\mathrm{p}=0,000^{* *}$ & & & $Z=-4,221$ & $\mathrm{p}=0,000^{* *}$ & \\
\hline \multirow[t]{2}{*}{$\begin{array}{c}\text { Carbohydrate } \\
(\%)\end{array}$} & $46,7 \pm 8,43$ & $49,0 \pm 15,75$ & $56,7 \pm 5,70$ & $57,0 \pm 8,50$ & $40,8 \pm 3,89$ & $40,0 \pm 4,75$ & $56,8 \pm 8,00$ & $60,0 \pm 10,75$ \\
\hline & & $t=-3,932$ & $\mathrm{p}=0,001^{* *}$ & & & $t=-7,195$ & $\mathrm{p}=0,000^{* *}$ & \\
\hline \multirow[t]{2}{*}{ Fiber (g) } & $26,9 \pm 10,97$ & $26,7 \pm 12,74$ & $36,2 \pm 11,89$ & $34,4 \pm 12,39$ & $19,3 \pm 6,37$ & $17,9 \pm 11,86$ & $29,3 \pm 7,84$ & $29,6 \pm 8,38$ \\
\hline & & $t=-2,308$ & $\mathrm{p}=0,028^{*}$ & & & $\mathrm{t}=-3,986$ & $\mathrm{p}=0,000^{* *}$ & \\
\hline \multirow[t]{2}{*}{ Protein (g) } & $63,8 \pm 19,20$ & $57,5 \pm 19,21$ & $91,0 \pm 23,98$ & $94,7 \pm 36,79$ & $49,5 \pm 19,63$ & $46,3 \pm 16,66$ & $62,9 \pm 18,57$ & $58,9 \pm 30,28$ \\
\hline & & $t=-3,539$ & $\mathrm{p}=0,001^{* *}$ & & & $Z=-2,337$ & $\mathrm{p}=0,019^{*}$ & \\
\hline \multirow[t]{2}{*}{$\begin{array}{l}\text { Animal protein } \\
(\mathrm{g})\end{array}$} & $30,5 \pm 14,20$ & $28,6 \pm 15,89$ & $36,3 \pm 16,58$ & $30,1 \pm 27,82$ & $24,3 \pm 18,50$ & $20,5 \pm 16,65$ & $17,3 \pm 11,36$ & $14,5 \pm 10,29$ \\
\hline & & $\mathrm{Z}=-0,942$ & $\mathrm{p}=0,346$ & & & $Z=-1,357$ & $\mathrm{p}=0,175$ & \\
\hline \multirow[t]{2}{*}{ Total fat (g) } & $88,4 \pm 30,40$ & $82,3 \pm 50,65$ & $94,3 \pm 16,79$ & $95,3 \pm 28,49$ & $80,8 \pm 21,24$ & $82,9 \pm 34,84$ & $83,5 \pm 28,09$ & $79,4 \pm 38,36$ \\
\hline & & $t=-0,686$ & $\mathrm{p}=0,500$ & & & $\mathrm{t}=-0,316$ & $\mathrm{p}=0,754$ & \\
\hline \multirow[t]{2}{*}{ PUFA (g) } & $20,7 \pm 12,20$ & $17,2 \pm 20,04$ & $17,3 \pm 6,70$ & $16,7 \pm 12,40$ & $20,3 \pm 8,96$ & $20,5 \pm 15,52$ & $15,5 \pm 14,99$ & $15,5 \pm 18,90$ \\
\hline & & $\mathrm{t}=0,952$ & $\mathrm{p}=0,350$ & & & $Z=-1,131$ & $\mathrm{p}=0,258$ & \\
\hline \multirow[t]{2}{*}{$\mathrm{n}-3(\mathrm{~g})$} & $1,8 \pm 1,02$ & $1,5 \pm 1,75$ & $2,2 \pm 0,95$ & $1,9 \pm 1,37$ & $1,6 \pm 1,16$ & $1,4 \pm 0,97$ & $1,8 \pm 1,12$ & $1,1 \pm 2,05$ \\
\hline & & $Z=-1,357$ & $\mathrm{p}=0,175$ & & & $Z=-0,094$ & $\mathrm{p}=0,925$ & \\
\hline \multirow[t]{2}{*}{$\mathrm{n}-6(\mathrm{~g})$} & $18,7 \pm 11,69$ & $15,9 \pm 18,61$ & $15,1 \pm 6,66$ & $13,7 \pm 10,70$ & $18,6 \pm 8,68$ & $18,9 \pm 13,93$ & $16,4 \pm 14,40$ & $12,9 \pm 18,75$ \\
\hline & & $t=1,093$ & $\mathrm{p}=0,285$ & & & $Z=-1,244$ & $\mathrm{p}=0,214$ & \\
\hline
\end{tabular}

${ }^{*} \mathrm{p}<0,05,{ }^{* *} \mathrm{p}<0,01$. Independent sample t-test was used to compare two independent groups in the data with normal distribution, and the mean and standard deviation were used. The "Mann-Whitney $U$ " test was used to compare two independent groups in the data with no normal distribution and is shown by the median \pm IQR. PUFA: polyunsaturated fatty acids, n-3: omega-3 fatty acids, n-6: omega-6 fatty acids

metabolism in diabetic individuals (25). But; if the daily total fat intake is high, is causing the fasting insulin concentration is increased (26). In healthy individuals, the recommended amount of consumption of PUFA has reduced the risk of diabetes (27). In a study comparing the food consumption of diabetic and healthy individuals: no difference was found between the groups in terms of dietary energy, carbohydrate and fiber intake, while the percentage of energy from fat was found to be higher in diabetic individuals. $(\mathrm{p}<0,05)(28)$. In this study, the energy intake in the patient group was found to be higher than in the healthy group $(\mathrm{p}<0,05)$. Significant differences were found between the patient and the healthy group in the amount of carbohydrate, fiber and protein consumed in the diet $(p<0,05)$ (Table 3$)$. It is thought that the lower amount of energy and macronutrients in the patient group is due to the individuals consuming the diabetic diet.

Dietary sources of carnitine are interaction with nutrition due to the role of various nutrients in their synthesis and their role in metabolism. Considering that the level of serum carnitine may change depending on the nutrient consumption of the individual, in this study has been assessed the relationship between serum carnitine level and with diet energy and nutrient intakes. A positive correlation was observed between serum carnitine levels and PUFA and n-6 intake of healthy male $(\mathrm{p}<0,05 ; \mathrm{r}=0,691$ and $\mathrm{p}<0,05 ; \mathrm{r}=0,706$ respectively). In healthy males, serum carnitine level is increasing due to PUFA and n-6 intake (Table 4). This of the result: that of PUFA increase of fatty acid oxidation in the liver and the activity of carnitine palmitoyltransferase- 1 enzyme is considered originate from the providing regulation peroxisome proliferator-activated receptor alpha (PPAR- $\alpha)$ (29). In female in the healthy group, a negative relationship was observed between serum carnitine levels and fiber intake. ( $\mathrm{p}<0,05, \mathrm{r}=-0,503$ ) (Table 5). Fiber sources in the diet are also a source of carbohydrates and protein intake decreases as carbohydrate intake increases. This suggests that the increase of fiber intake may cause a decrease in carnitine intake.

Since carnitine is involved in the metabolism of fatty acids and affects enzyme activity of pyruvate dehydrogenase; it is thought to be an interaction between with carnitine some biochemical parameters and HOMA-IR (30). In a study conducted with intravenous carnitine supplementation, insulin sensitivity 
Table 4. Relationship between serum carnitine levels and some parameters in individuals

\begin{tabular}{|c|c|c|c|c|c|c|c|c|}
\hline \multirow[b]{3}{*}{ Parameters } & \multicolumn{4}{|c|}{ Male } & \multicolumn{4}{|c|}{ Female } \\
\hline & \multicolumn{2}{|c|}{ Patients (n:16) } & \multicolumn{2}{|c|}{ Healthy (n:16) } & \multicolumn{2}{|c|}{ Patients (n:16) } & \multicolumn{2}{|c|}{ Healthy (n:16) } \\
\hline & $\mathbf{r}$ & $\mathrm{p}$ & $\mathbf{r}$ & $\mathrm{p}$ & $\mathbf{r}$ & $\mathrm{p}$ & $\mathbf{r}$ & $\mathrm{p}$ \\
\hline $\begin{array}{l}\text { Dietary energy } \\
\text { intake (kkal) }\end{array}$ & $-0,406$ & 0,119 & $-0,144$ & 0,594 & 0,021 & 0,940 & $-0,291$ & 0,274 \\
\hline $\begin{array}{l}\text { Dietary carbo- } \\
\text { hydrate intake } \\
\text { (g) }\end{array}$ & $-0,496$ & 0,051 & $-0,138$ & 0,610 & 0,013 & 0,961 & $-0,338$ & 0,200 \\
\hline $\begin{array}{c}\text { Carbohydrate } \\
\text { percentage (\%) }\end{array}$ & $-0,121$ & 0,657 & $-0,102$ & 0,707 & 0,069 & 0,800 & 0,112 & 0,679 \\
\hline $\begin{array}{l}\text { Dietary fiber } \\
\text { intake }(\mathrm{g})\end{array}$ & $-0,411$ & 0,114 & 0,144 & 0,594 & 0,451 & 0,079 & $-0,503$ & $0,047^{*}$ \\
\hline $\begin{array}{l}\text { Dietary protein } \\
\text { intake }(\mathrm{g})\end{array}$ & 0,075 & 0,782 & $-0,121$ & 0,656 & 0,175 & 0,120 & $-0,374$ & 0,154 \\
\hline $\begin{array}{l}\text { Dietary animal } \\
\text { protein intake } \\
\text { (g) }\end{array}$ & 0,113 & 0,676 & $-0,018$ & 0,948 & $-0,037$ & 0,892 & 0,006 & 0,983 \\
\hline $\begin{array}{l}\text { Dietary total fat } \\
\text { intake }(\mathrm{g})\end{array}$ & $-0,267$ & 0,317 & 0,026 & 0,922 & 0,115 & 0,670 & $-0,435$ & 0,092 \\
\hline $\begin{array}{c}\text { Dietary PUFA } \\
\text { intake }(\mathrm{g})\end{array}$ & $-0,187$ & 0,489 & 0,691 & $0,003^{* *}$ & $-0,389$ & 0,137 & $-0,044$ & 0,871 \\
\hline $\begin{array}{l}\text { Dietary n-3 } \\
\text { intake (g) }\end{array}$ & $-0,006$ & 0,983 & 0,341 & 0,196 & 0,034 & 0,901 & $-0,242$ & 0,367 \\
\hline $\begin{array}{l}\text { Dietary n-6 (g) } \\
\text { intake }\end{array}$ & $-0,385$ & 0,141 & 0,706 & $0,002^{* *}$ & $-0,262$ & 0,327 & $-0,274$ & 0,305 \\
\hline $\begin{array}{l}\text { Serum glucose } \\
(\mathrm{mg} / \mathrm{dL})\end{array}$ & $-0,121$ & 0,656 & $-0,345$ & 0,191 & 0,063 & 0,816 & $-0,344$ & 0,192 \\
\hline $\begin{array}{l}\text { Serum insulin } \\
(\mathrm{mU} / \mathrm{L})\end{array}$ & $-0,161$ & 0,553 & $-0,144$ & 0,594 & $-0,080$ & 0,770 & $-0,374$ & 0,154 \\
\hline HOMA-IR & $-0,201$ & 0,455 & $-0,174$ & 0,520 & 0,005 & 0,985 & $-0,450$ & 0,080 \\
\hline $\begin{array}{l}\text { Body weight } \\
\text { (kg) }\end{array}$ & 0,110 & 0,686 & $-0,115$ & 0,672 & $-0,205$ & 0,446 & $-0,676$ & $0,004^{* *}$ \\
\hline BMI $\left(\mathrm{kg} / \mathrm{m}^{2}\right)$ & 0,068 & 0,801 & $-0,418$ & 0,107 & $-0,015$ & 0,956 & $-0,632$ & $0,009^{* *}$ \\
\hline $\begin{array}{l}\text { Body fat per- } \\
\text { centage (\%) }\end{array}$ & $-0,131$ & 0,628 & $-0,032$ & 0,905 & $-0,154$ & 0,570 & $-0,424$ & 0,102 \\
\hline $\begin{array}{l}\text { Body fat mass } \\
(\mathrm{kg})\end{array}$ & $-0,005$ & 0,984 & $-0,094$ & 0,729 & $-0,211$ & 0,432 & $-0,526$ & $0,036^{*}$ \\
\hline
\end{tabular}

${ }^{*} \mathrm{p}<0,05,{ }^{* *} \mathrm{p}<0,01$. Quantitative evaluation of the relationship of two data in the normal distribution with "Pearson", the data are not normally distributed "Spearman" is used in the correlation coefficient. PUFA: polyunsaturated fatty acids, n-3: omega-3 fatty acids, n-6: omega-6 fatty acids, HOMA-IR: homeostasis model assessment of insülin resistance, BMI: body mass index.

was increased in diabetic individuals with insulin resistance, and an increase was observed in the use of glucose by tissues in both diabetic and healthy individuals. $(\mathrm{p}<0,05)(13)$. In another study conducted in poorly controlled $(\mathrm{HbAlc}>8)$ diabetic patients, orlistat alone or orlistat with $2 \mathrm{~g} /$ day of L-carnitine were given for one year. At the end of the study: a faster and greater decrease was observed in $\mathrm{HbAlc}$, fasting and postprandial blood glucose, fasting insulin levels and HOMA-IR values in the group supplemented with L-carnitine $(\mathrm{p}<0,05)(31)$. However, in another study in which $3 \mathrm{~g} /$ day oral L-carnitine supplementation was applied for 4 weeks in individuals with type-2 diabetes; It was noted that carnitine supplementation did not provide any change in insulin sensitivity, and the effect of longer-term use should be examined. It was stated that this situation may be caused by the individuals' diets and physical activities not being the same. (17). In a study conducted in healthy individuals: although an increase was achieved in the oxidation of LCFA by giving $1 \mathrm{~g}$ L-carnitine support 3 times a day for 10 days $(\mathrm{p}<0.01)$, no change was observed in serum glucose and HbA1c levels (32). Studies have generally focused on carnitine supplementation $(17,31,32)$; however, the relationship between fasting blood glucose, insulin and HOMA-IR value and serum carnitine levels has been investigated in this study without carnitine supplementation. In this study, there was no significant relationship between fasting blood glucose, insulin and HOMA-IR value and serum carnitine levels according to disease in both genders ( $p>0,05)$ (Table 4$)$. The relationship between biochemical parameters of individuals and with HOMA-IR value serum carnitine level can be examined in future studies by increasing the number of sample size. 
Serum carnitine level; since it is affected by obesity and chronic disease, it is thought that there may be a relationship between the anthropometric measurements of the individuals and the serum carnitine level. In a study, when the high-fat diet and L-carnitine supplement added to the diet were compared in obese mice, a significant reduction in body weight, energy intake and food intake was noted in the L-carnitine supplemented group ( $\mathrm{p}<0,05)$. Also, abdominal fat was found to be more in the high-fat diet compared to the carnitine supplemented group (33). In another study, plasma L-carnitine levels were found to be low in diabetic individuals. Moreover, a negative correlation was observed between L-carnitine level and BMI, triglyceride and fasting blood glucose (34). In this study, there has not been observed a significant correlation between serum carnitine levels and anthropometric measurements according to disease in males and females $(p>0,05)$. Only female in healthy group had been observed a negative correlation between serum carnitine levels and body weight $(\mathrm{p}<0,05 ; \mathrm{r}=-0,676), \mathrm{BMI}(\mathrm{p}<0,05 ; \mathrm{r}=-$ $0,632 ;)$, and body fat mass ( $\mathrm{kg})(\mathrm{p}<0,05 ; \mathrm{r}=-0,526)$. According to the results obtained; in healthy female: as the body weight, BMI, and body fat mass increase, the serum carnitine level decreases (Table 4). This situation is an indication that the serum carnitine level may be fallen due to obesity. In a meta-analysis study, the effect of carnitine supplementation on body composition was examined. It was concluded that carnitine supplementation provides a reduction in BMI, body weight and body fat mass. It is suggested that the relationship between carnitine and obesity is due to the effect of carnitine on blood glucose control and lipid lowering activities (35). Since there is not enought study evaluating the relationship between anthropometric measurements of individuals and serum carnitine levels, it is thought that this result will guide future studies.

As a result, the serum carnitine level changes due to the changing metabolic status in individuals with diabetes. There is also a relationship between individuals' nutrient intake and body composition and carnitine level. It is thought that this study will contribute to the literature in terms of examining the relationship between food consumption and carnitine level in patients with type 2 diabetes and healthy controls.

\section{Conflicts of interest}

The author declares no conflicts of interest related to this study.

\section{References}

1. Mamoulakis D, Galanakis E, Dionyssopoulou E, Evangeliou A, Sbyrakis S. Carnitine deficiency in children and adolescents with type 1 diabetes. Journal of Diabetes and Its Complications, 2004;18(5), 271-274.

2. Gülçin İ. Antioxidant and antiradical activities of L-carnitine. Life Sciences, 2006;78(8), 803-811

3. Deniz G. Karnitin: sentez, metabolizma, fonksiyon ve iskemik kalpte terapötik önemi. Turkiye Klinikleri Journal of Medical Sciences, 1999;19(1), 55-62.

4. Yavuz H, Kurtoğlu F. Biyokimyasal özellikleri ile L-karnitin. Journal of The Faculty of Veterinary Medicine, İstan- bul University, 2012;38(2), 207-218.

5. Mahmood M D, Al-Youzbaki W B, Aziz B N. Effects of L-carnitine on glycemic control, serum insulin and c-peptide level in alloxan-induced diabetic rabbit. Pharmacie Globale, 2014;5(2), 1.

6. Tamamoğullari N, Siliğ Y, İçağasioğlu S, Atalay A. Carnitine deficiency in diabetes mellitus complications. Journal of Diabetes and Its Complications, 1999;13(5), 251-253.

7. Sütken E, Uslu S, Aral E, Özdemir F, Alataş, Ö. Diabetik sıçanlarda L-karnitin, n-asetil- $\beta$-d-glukozaminidaz düzeyleri ve erken diabetik nefropatide plazma fibronektinin rolü. Anadolu University Journal of Science And Technology, 2009; 10:2

8. Korkmaz S, Yıldız G, Kılıçlı F, Yılmaz A, Aydın H, İçağasıoğlu S, Candan F. Düşük L-karnitin düzeyleri: Tip 2 diyabetes mellitus olgularında noktürnal kan basıncı değişikliklerinin bir nedeni olabilir mi?. The Anatolian Journal of Cardiology, 2011;1, 57-63.

9. Ringseis R, Keller J, Eder K. Role of carnitine in the regulation of glucose homeostasis and insulin sensitivity: evidence from in vivo and in vitro studies with carnitine supplementation and carnitine deficiency. European Journal of Nutrition, 2012;51(1), 1-18.

10. Yoon K H, Lee J. H, Kim J W, Cho J H, Choi Y H, Ko S H, Son H Y. Epidemic obesity and type 2 diabetes in Asia. The Lancet, 2006;368(9548), 1681-1688.

11. Reda E, D'iddio S, Nicolai R, Benatti P, Calvani M. The carnitine system and body composition. Acta diabetologica, 2003;40(1), s106-s113.

12. Peluso G, Mingrone G, Barbarisi A, Petillo O, Greco A V, Indiveri $C$, Calvani M. Decreased skeletal muscle carnitine translocase impairs utilization of fatty acids in insulin-resistant human muscle. Front Biosci, 2002;7, A109-A116.

13. Mingrone G, Greco A V, Capristo E, Benedetti G, Giancaterini A, Gaetano A D, Gasbarrini G. L-carnitine improves glucose disposal in type 2 diabetic patients. Journal of the American College of Nutrition, 1999;18(1), 77-82.

14. Derosa G, Maffioli P, Ferrari I, D’Angelo A, Fogari E, Palumbo I, Randazzo S, Cicero A F. Orlistat and L-carnitine compared to orlistat alone on insulin resistance in obese diabetic patients. Endocrine Journal, 2009;57(9), 777-786.

15. Sirtori C R, Calabresi L, Ferrara S, Pazzucconi F, Bondioli A, Baldassarre D, Birreci A, Koverech A. L-carnitine reduces plasma lipoprotein (a) levels in patients with hyper Lp (a). Nutrition, Metabolism and Cardiovascular Diseases: 2000;10(5), 247-251.

16. Malaguarnera M, Vacante $M$, Avitabile T, Malaguarnera M, Cammalleri L, Motta M. L-Carnitine supplementation reduces oxidized LDL cholesterol in patients with diabetes. The American Journal of Clinical Nutrition, 2009;89(1), 71-76.

17. Gonzalez-Ortiz M, Hernandez-Gonzalez S O, Hernandez-Salazar E, Martinez-Abundis E. Effect of oral L-carnitine administration on insulin sensitivity and lipid profile in type 2 diabetes mellitus patients. Annals of Nutrition 
and Metabolism, 2008;52(4), 335-338.

18. Bebis Nutrition Data Base Software Data Base. The German Food Code and Nutrient Data Base (BLS II.3, 1999) with additions from USDA-sr and other sources, Istanbul, Turkey. 2004

19. Wallace T M, Levy J C, Matthews D R. Use and abuse of HOMA modeling. Diabetes Care, 2004;27(6), 1487-1495.

20. Bouchouirab F Z, Fortin M, Noll C, Dubé J, Carpentier A C. Plasma palmitoyl-carnitine (AC16: 0) is a marker of increased postprandial nonesterified incomplete fatty acid oxidation rate in adults with type 2 diabetes. Canadian journal of diabetes, 2018;42(4), 382-388.

21. Bene J, Hadzsiev K, Melegh B. Role of carnitine and its derivatives in the development and management of type 2 diabetes. Nutrition \& diabetes, 2018;8(1), 1-10.

22. De Palo E, Gatti R, Sicolo N, Padovan D, Vettor R, Federspil G. Plasma and urine free L-carnitine in human diabetes mellitus. Acta Diabetologica, 1981;18(1), 91-95.

23. American Diabetes Association (ADA). Standards of medical care in diabetes-2016, Diabetes Care, 2016;39(1).

24. Köseoğlu Ö. Tip 2 diyabetik bireylerde beslenme eğitiminin diyabet durumu ve beslenme alışkanlıklarına etkisi. Yayımlanmamış Yüksek Lisans Tezi, Başkent Üniversitesi Sağlık Bilimleri Enstitüsü, Ankara. 2015.

25. Wolfram T, Ismail-Beigi F. Efficacy of high-fiber diets in the management of type 2 diabetes mellitus. Endocrine Practice, 2010;17(1), 132-142.

26. Marshall J A, Bessesen D H, Hamman R F. High saturated fat and low starch and fibre are associated with hyperinsulinaemia in a non-diabetic population: the San Luis Valley Diabetes Study. Diabetologia, 1997;40(4), 430-438

27. Salmeron J, Hu F B, Manson J E, Stampfer M J, Colditz G A, Rimm E B, Willett W C. Dietary fat intake and risk of type 2 diabetes in women. The American Journal of Clinical Nutrition, 2001;73(6), 1019-1026

28. Özpak Akkuş Ö. Comparison of serum vitamin D, calcium and magnesium levels with nutritional habits among type 2 diabetic and nondiabetic individuals. Başkent University, Institute of Health Sciences, Nutrition and Dietetic Program, PhD Thesis, Ankara, 2015.

29. El-Badry A M, Graf R, Clavien P A. Omega 3-Omega 6: What is right for the liver?. Journal of Hepatology, 2007;47(5), 718-725.

30. Reuter S E, Evans A M. Carnitine and acylcarnitines. Clinical Pharmacokinetics, 2012;51(9), 553-572

31. Derosa G, Maffioli P, Ferrari I, D’Angelo A. Fogari E, Palumbo I, Cicero A F. Orlistat and L-carnitine compared to orlistat alone on insulin resistance in obese diabetic patients. Endocrine Journal, 2010;57(9), 777-786.

32. Müller D M, Seim H, Kiess W, Richter T. Effects of oral L-carnitine supplementation on in vivo long-chain fatty acid oxidation in healthy adults. Metabolism-Clinical and Experimental, 2002;51(11), 1389-1391.

33. Mun E G, Soh J R, Cha Y S. L-carnitine reduces obesity caused by high-fat diet in C57BL/6J mice. Food Science and Biotechnology, 2007;16(2), 58-63.

34. Ramazani M, Qujeq D, Moazezi Z. Assessing the levels of L-carnitine and total antioxidant capacity in adults with newly diagnosed and long-standing type 2 diabetes. Canadian journal of diabetes, 2019;43(1), 46-50.

35. Talenezhad N, Mohammadi M, Ramezani-Jolfaie N, Mozaffari-Khosravi H, Salehi-Abargouei A. Effects of 1-carnitine supplementation on weight loss and body composition: A systematic review and meta-analysis of 37 randomized controlled clinical trials with dose-response analysis. Clinical nutrition ESPEN. 2020 